\title{
St. Nicholas of Tolentino monastery and church in Actopan, Hidalgo: preservation, surveying and reuse of a heritage building in Mexico
}

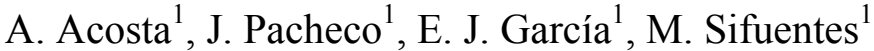 \\ \& J. M. Rodríguez ${ }^{2}$ \\ ${ }^{I}$ Universidad Autónoma de Aguascalientes, Mexico \\ ${ }^{2}$ Universidad de Guanajuato, Mexico
}

\begin{abstract}
During the sixteenth century the process of the conquest of Mesoamerica was complex and it took more than 50 years to suppress the resistance of the Indian population. In that length of time Augustinians played a prominent role. St. Nicholas of Tolentino monastery was designed to exercise charity and today it is one of the most important heritage buildings in the State of Hidalgo, Mexico. The Augustinian Hermits had a devotion to reading and studying of sacred scriptures and used the monastery and the church during several years. In spite of frequent conflicts during the nineteenth century in Mexico the church and the convent still preserve their original architecture. By the second half of the twentieth century the monastery declined, and the Mexican government decided to restore it. The purpose of this paper is to expose benefits of using recent surveying methods, as well as the possible reuse of the monastery as a gallery. Also with the help of a MALA ramac X3M radar we surveyed specific walls and certain floor surfaces inside the church, in order to find undiscovered rooms. Non destructive evaluation techniques can be useful to determine the reuse of historic buildings.
\end{abstract}

Keywords: heritage buildings, reusing buildings, surveying, historic preservation in Mexico. 


\section{Introduction}

Historic preservation nowadays is more accurate with the help of modern technology and the use of new research methods. It is worth writing about St. Nicholas of Tolentino monastery and church because they are some of the most important historic buildings from the sixteenth century in Mexico. Surveying these buildings was done in order to find undiscovered rooms and considering the possibility of including more exhibition areas or passages in the reuse of the convent. The results depended on measurement techniques and new strategies on retrofitting. The main monastery situated in Actopan is 'Plateresco' style and has an influence of Middle Age architecture from Spain. The main historic buildings of Actopan are in a pure state today, keep mysteries and hidden secret rooms. Historic buildings in Mexico are protected by law and the office that promotes their preservation is the INAH. It was necessary to ask for authorization from the INAH in order to evaluate the building and to survey it. It is important to mention that Kubler [1] was the most influential writer of 'Plateresco', and the method used in this paper includes recognizing the areas to be explored, surveying the buildings with a Geo-radar and also using a contemporary critical thought, with vertical and horizontal dimensions, written by Soja [2]; which means the interplay of history and geography. Also studying Groat and Wang [3] was useful in choosing the research method, and examining Kubler's work was helpful. The principal results led us to conclude that we found a tunnel under the altar area on the church, although we propose an archeological exploration in the near future to reinforce the conclusion.

\section{Augustinians and monasteries in Mexico}

Spanish colonization produced several religious buildings, such as monasteries, churches and missions in the whole country. The Augustinians who arrived in Mexico during the sixteenth century came to practice Catholicism and created a climate of religious tolerance at the beginning, so in the paintings and sculptures there were different forms of syncretism, and this is recognized in the mixing of different religious symbols -Indian and Spanish. Also Augustinians had the ability to adjust their buildings in their adopted land to climatic conditions. 'Plateresco' style had its genesis in Mexico and over the last two decades of the sixteenth century it spread across the Mexican high plateau. The 'Plateresco' style was influenced by the Middle Age architecture built in Spain and in some other European countries. Kubler mentioned that a lot of religious architecture from the sixteenth century was built basically with a nave. Monastic architecture in the State of Hidalgo was so well adapted to its location that it endured; maybe the use of certain shapes in the buildings could give us a key to explain why they continue existing for a long time. 


\section{The main heritage building in Actopan, Hidalgo}

The monastery was built on July 8,1546 . In the 'Mezquital' province is situated Actopan, not very far from Mexico City. Later on, in 1868, the State of Hidalgo was founded. It looks like time did not do anything to the memory and perspective of the main building. The mystery is caught in the main aisles of the monastery and the old paintings on the walls are still beautifully expressed. Mexico believes in traditions and Actopan's monastery and church are part of them. These old buildings have not changed a lot since they were first built. The historic monastery is in a pure state, the small rooms or 'cells' without much furniture -in which the monks used to live, were kind of dark. As Madge and Peckham [4] suggests: man, for himself, struggles with life and creation. The space for reading and studying looks immaculate, so the preservation of cells should follow basic principles, referring to Tyler [5]. The 'cells' show freedom from superfluous adornment too. Also the 'cells' show an interest in how rooms relate to one another in terms of volume. The monastery was a place to pray and think. The second floor includes the 'cells' -as small sections that together form larger structures with an aisle, also surrounding the main 'patio'. On the second floor the interiors become more closed, and thinking is about cultivating the loneliness. The convent was an institution and the large fortress like housed a lot of monks dedicated to charity. The cloister surrounding the patio is very typical in this architecture style. Also it includes a very imaginative structural engineering. But these types of buildings always contain mystery places and hidden secrets. Modern surveying methods were of big help in searching for undiscovered rooms inside and under the main historic buildings of Actopan.

\section{Surveying the monastery and church}

There is an evaluator of the monastery's quality and this is basically the consumers or users. Arnold [6] explains that the users, producers and interpreters of space all play equally important roles in the understanding of it. The frequently visitor who recognizes the rooms, and likes to walk inside and outside the building, observes details and can tell if the use of the building is appropriate. Scanned areas were basically determined on a number of clear remarks made by the main administrator, who collected useful data for several years. We also identified a room with no access, situated among the Pilgrims Portal, the church and the De Profundis room, fig. 1. We also decided to use a non destructive method to explore it and we thought that using a Geo Radar was a good choice.

The current official bureau in Mexico dedicated to promoting the preservation of historic buildings, named: the National Institute of Anthropology and History (INAH) consider a building for the status of "Monument" only if it was built before 1900. After this date, all important buildings, in terms of esthetics or architectural value, can be consider for the category of "Artistic" buildings, promoted by the National Institute of the Beauty Arts (INBA). So first of all we decided to ask for permission to the INAH office to practice some explorations in the historic buildings, and they answered back that we could do them with the 


\section{FIRST FLOOR}

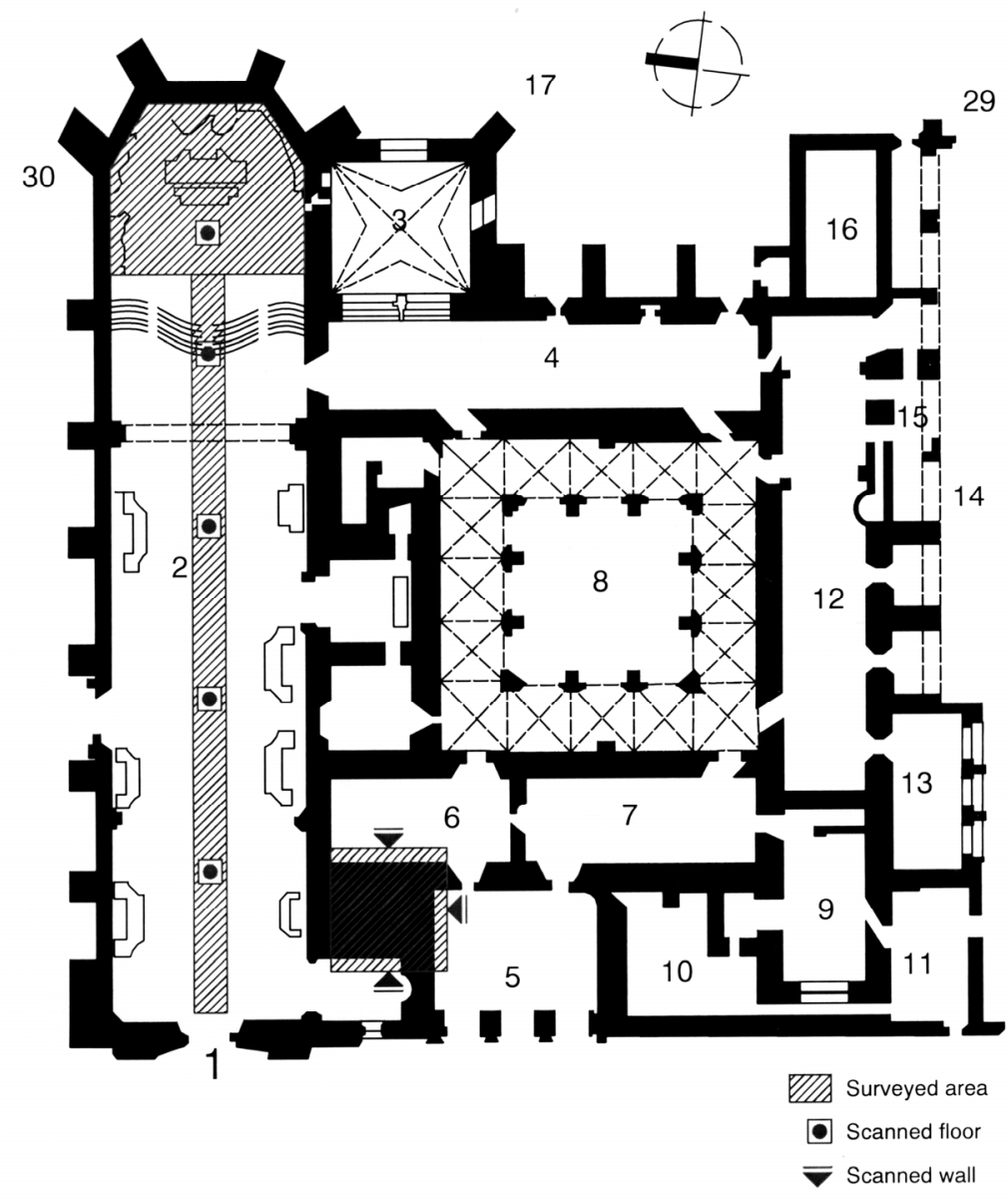

1.- Church's main gate. 2.- Audience area. 3.- Baptistery. 4.- Chapter House (Now the Vestry). 5.- Pilgrims Portal. 6.- Room "De Profundis." 7.- Lobby (Sale of books). 8.- Cloister. 9.- Kitchen. 10.- Kitchen Patio. 11.- Kitchen Patio. 12.- Dining Room (refectory). 13.- Three Arches Terrace.14.- Gardens. 15.- Outer Hall. 16.- Septic Tank. 17.- Back Yards.

Figure 1: $\quad$ Scanned areas were determined on a number of clear remarks made by the main administrator, who collected useful data for several years.

Geo Radar and they even offered some help. Also they told us to be careful with the paintings and not to make holes on the walls. 
The Geo Radar is similar to conventional radars used in airports to detect airplanes, but the waves go through the soil instead of the air. The radio detecting and ranging (radar) transmits waves and responds depending on types of materials. The Geo radar uses a double antenna to send and receive electromagnetic waves.

The first explorations were done with a MALA ramac X3M radar, including a $500 \mathrm{MHz}$ antenna. This radar has a $2 \mathrm{~m}$ depth range and can identify differences in the composition of scanned walls. We made horizontal explorations in different heights on the wall, fig. 2. Scanning the walls was more difficult than what we thought it would be. A person was en routing the radar, more people carried the batteries, the laptop and the radar. Also we had a photographer and a cameraman to register the research. Some people were watching the results and of course the building's administrator, a priest, and a delegate from the INAH.

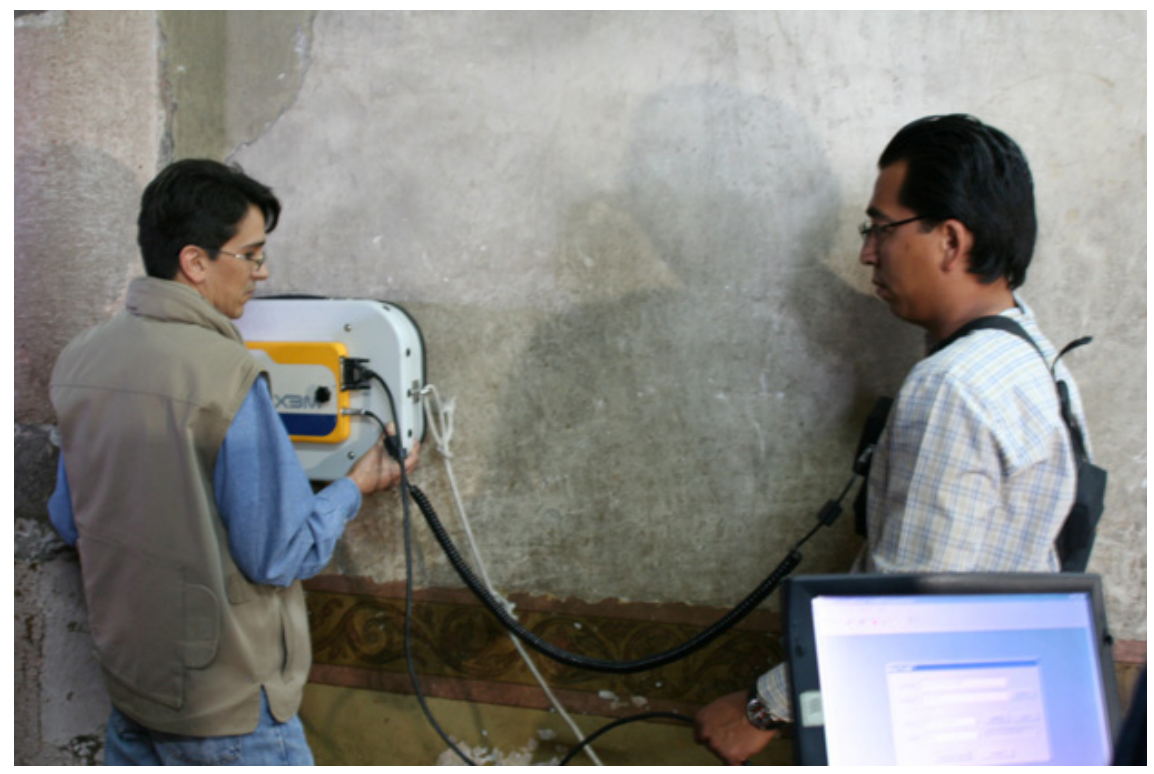

Figure 2: With the help of a MALA ramac X3M radar we surveyed specific walls and floor surfaces inside the church in order to find undiscovered rooms.

After 28 explorations we observed that the graphic bars produced by the radar were very similar and continuous. We could see a lack of noise on the bars and with just a few interruptions, fig. 3. In some cases a vertical exploration was done, but basically horizontal surveying was used.

Also the church was explored, but using a bigger antenna to search for empty spaces underground. The exploration was lineal, right in the middle of the main aisle in the nave, and on the main altar area. These explorations were done with a MALA ramac X3M radar, including a $250 \mathrm{MHz}$ antenna. 


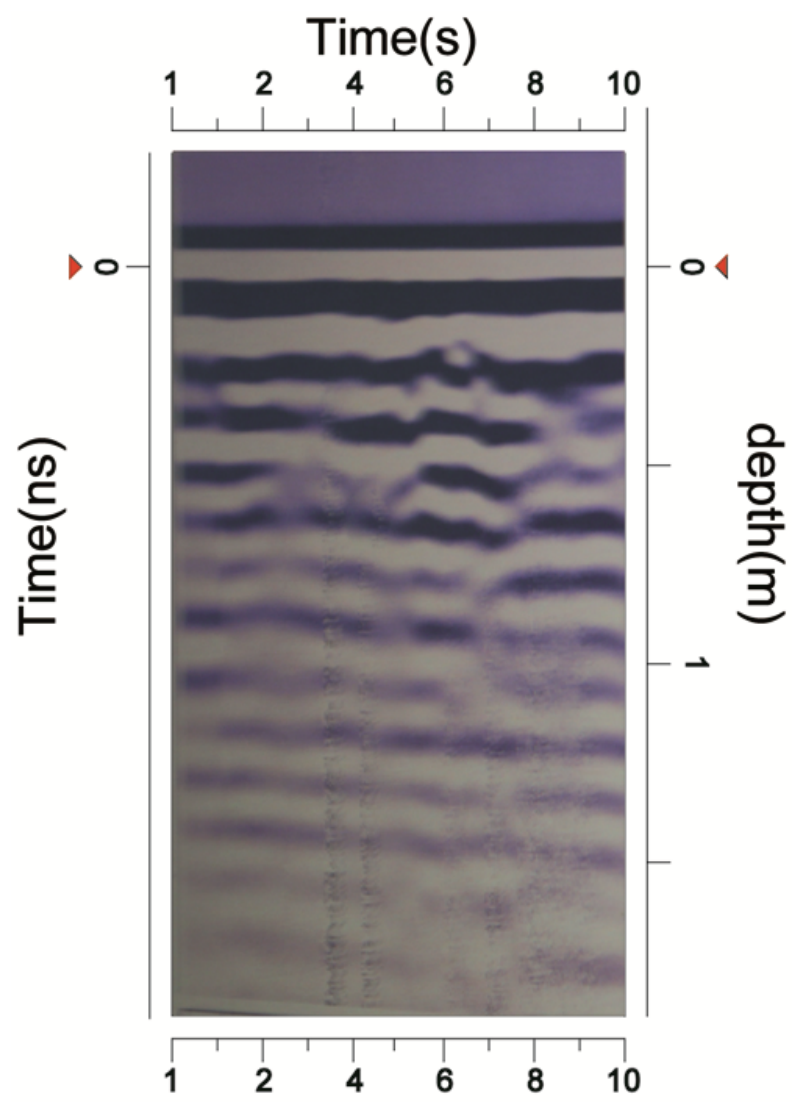

Figure 3: After 28 explorations we observed that the graphic bars produced by the radar were very similar and continuous.

\section{Reusing the monastery}

Augustinians had their own organizing principles and the monastery architecture was really well designed. The use of evidence from the past, for example history, can help design and improve the reuse of the buildings. Even though historical study of the building is necessary, we have to deal with the reuse and the interpretation of present-day situations. This means the new furniture in the design can be a product of the present and not the past. The old building is a therapy and to understand the building historically is necessary to walk inside and outside as a visitor and as a designer. In order to obtain a good reuse of the building, the designer should consider the constructed nature of important events. The reuse should consider a contemporary critical thought. Soja says: 'Geography may not yet have displaced history at the heart of contemporary theory and criticism, but there is a new animating polemic on the theoretical and political agenda, one which rings with significantly different ways of seeing time 
and space together, the interplay of history and geography, the 'vertical' and 'horizontal' dimensions of being in the world freed from the imposition of inherent categorical privilege'. The reuse of historic buildings should include a relationship between the past and the present. The cells that are datable to the sixteenth century can be reused now as part of a gallery; also a critical theory can be used to improve the designs, as Borden and Rendell [7] suggests.

We can say there is enough room to accommodate deliveries of paintings and sculptures; the museum could have its own acquisitions from legacies and donations thus embellishing the collection with masterpieces from national collections. These collections could be presented chronologically in the aisles and respective sections of the convent.

\section{Conclusions}

The original design of the building articulated daily activities of monks in relation to space and were adequate. The architectural boundaries were very clear and depended on monks' activities. Nowadays these boundaries could be use to control the new retrofitting solutions.

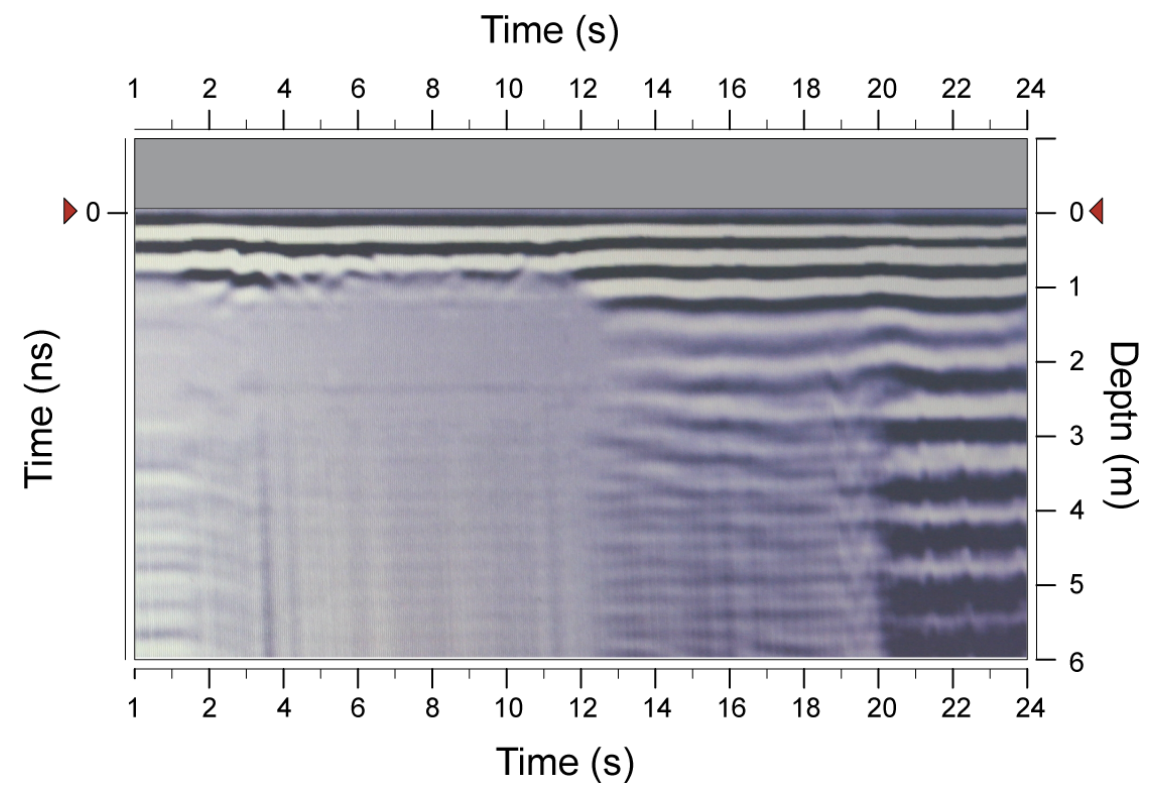

Figure 4: Using a $250 \mathrm{MHz}$ antenna caused a change in the frequencies and we could explore as deep as six metres under the floor. In this case the energy reflected was not constant in the altar area.

After the 28 explorations on the three walls we found out that the empty space was in fact full of the same material used to build the walls. It is important to mention that another exploration was done at the same time in the central aisle of 
the nave, and nothing was found. The most interesting conclusions came during the surveying of the altar area inside the church: by using a $250 \mathrm{MHz}$ antenna caused a change in the frequencies and we could explore as deep as six metres underground. In this case the energy reflected was not constant, fig. 4. The graphic shows no bars in four meters length of floor surface (12 seconds motion) and after one meter depth. This means a presence of different material, less conductivity or a great possibility of an empty space (air).

During the nineteenth century there were a few wars, also social movements, and strong political changes occurred in the country. So it was very common to make tunnels to communicate different places inside a town. For example: between an altar of a church and a house, or a church with another church. People used these tunnels to escape from attacks too. Also there was a frequent destruction of religious buildings in the nineteenth century.

Applying Soja's theory by combining history and geography, we can say now that we found a tunnel system under the altar of the church of Actopan. We finally consider that it is necessary another type of exploration to recognize what we found with the radar. In the reuse of the buildings, of course the tunnels should become part of it. The next step must be to suggest archaeological works on the main altar area (apse) in the next future.

\section{References}

[1] Kubler, G. Mexican Architecture of the Sixteenth Century, Fondo de Cultura Económica: Mexico, pp. 241-316, [1948] Third reprint 1992.

[2] Soja, E., Postmodern Geographies, The Reassertion of Space in Critical Social Theory, Verso: Great Britain, pp. 10-42, [1989] Eight impression 2003.

[3] Groat, L. \& Wang, D, Architectural research methods, John Wiley \& Sons, Inc.: United States of America and Canada, pp. 74-98, 2002.

[4] Madge, J. \& Peckham, A. (Ed.), Narrating Architecture, A retrospective anthology, Routledge: USA and Canada, pp. 228-252.

[5] Tyler, N., Historic Preservation, an introduction to its history, principles, and practice, W.W. Norton \& Company: New York and London, pp. 139$153,2000$.

[6] Arnold, D., Reading Architectural history, Routledge: London and New York, pp. 127-142, 2002.

[7] Borden, L. \& Rendell, J., InterSections, Architectural Histories and Critical Theories, Routledge: London and New York, pp. 3-23, 2000. 